\title{
The Persimmon Borer Sannina uroceriformis Walker, Pest of Persimmon 1
}

Russell F. Mizell, $I I I^{2}$

\section{Introduction}

The persimmon borer, Sannina uroceriformis Walker, (Lepidoptera: Sesiidae) attacks the American persimmon, Diospyros virginiana, which is its only known host. The persimmon borer is a pest because the native, American persimmon is used as the rootstock for the fruit-producing scions of the Japanese persimmon, D. kaki. This clearwing moth is found attacking native persimmon throughout the range of its host along the Atlantic Coast from New Jersey to Florida and westward to Texas, Oklahoma, Missouri, Kansas, Ohio, and Indiana.

Oriental persimmon has been grown throughout Florida and other gulf coast states for many years. At one time an estimated 22,000 trees were grown in Florida alone. Today, there are a few hundred acres of persimmon in Florida; however, the crop has great potential to expand commercially. There are new cultivars available, especially of the non-astringent type that are very tasty and amenable to shipment. Oriental persimmon is also a popular dooryard fruit that is relatively easy to grow.

\section{Description}

The adult moths (Figures 1 and 2) are bluish black, wasplike, with a wingspan of 28 to $32 \mathrm{~mm}$. They appear to mimic the large black and red wasp, Lophopompilis atrox. The female is slightly larger than the male. Typically, the moth has a distinctive orange band across the abdomen, though this band is lacking in some. The blue-black color and orange abdominal band cause this species to be confused with the female of the more common peachtree borer, Synanthedon exitiosa, which has transparent hind wings. The persimmon borer adult has opaque fore wings somewhat opaque hind wings with small transparent areas between veins at the base of the wings. There are distinct anal tufts in males with five long hair pencils on abdominal segment 8 , consisting of two lateral pairs and one anal (Figure 2).

Moths emerge and occur from March to July in the Gulf Coast region and mostly in June and July in the northern range. Moths emerge in the morning and mate from late morning until noon. Females deposit eggs on the bark of the lower trunks of host trees or sometimes drop their eggs on the ground around the base of the trees. On hatching, larvae move to

1. This document is ENY-835 (IN669), one of a series of Entomology and Nematology Department, Florida Cooperative Extension Services, Institute of Food and Agricultural Sciences, University of Florida. Publication Date 07/06. Please visit the EDIS website at http://edis.ifas.ufl.edu.

2. Russell F. Mizell, III, professor, Extension Specialist, Pest Management, North Florida Research and Education Center-Quincy, Cooperative Extension Service, Institute of Food and Agricultural Sciences, University of Florida, Gainesville, FL 32611.

The Institute of Food and Agricultural Sciences (IFAS) is an Equal Opportunity Institution authorized to provide research, educational information and other services only to individuals and institutions that function with non-discrimination with respect to race, creed, color, religion, age, disability, sex, sexual orientation, marital status, national origin, political opinions or affiliations. U.S. Department of Agriculture, Cooperative Extension Service, University of Florida, IFAS, Florida A. \& M. University Cooperative Extension Program, and Boards of County Commissioners Cooperating. Larry Arrington, Dean 


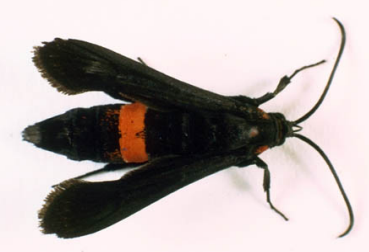

UGA3056031

Figure 1. The adult female persimmon clearwing moth Credits: James Solomon, USDA Forest Service, www.insectimages.org

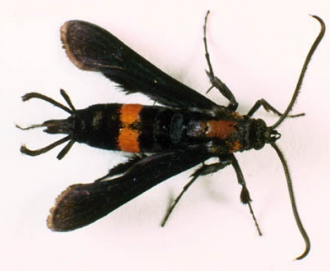

UGA3056032

Figure 2. The adult male persimmon clearwing moth Credits: James Solomon, USDA Forest Service, www.insectimages.org

suitable sites, usually at or near the root collar, to bore into the bark, but attacks sometimes are initiated 30 to $60 \mathrm{~cm}$ above ground. Young larvae are dull or grayish white and later become almost white, except for a brown head and a light brown hardened cuticle area dorsally on the prothorax. Young larvae begin feeding and mine downward in the cambium (Figure 3 ). Mines occasionally meander but usually extend essentially straight down. At or slightly below the groundline, larvae extend tunnels into the wood, sometimes to the center of both the lateral and tap roots. Root galleries most commonly extend down to a depth of 20 to $25 \mathrm{~cm}$, but can reach 43 to $56 \mathrm{~cm}$ in the taproots (Figure 4). Mature larvae are about 24 to $30 \mathrm{~mm}$ long. Larvae overwinter in their galleries below the soil line and pupate during spring. When ready to pupate, larvae extend their galleries upward in the roots to ground line or just above. They chew through the bark and construct large coccons upward and outward from the bark (Figure 5). These tubelike cases are made of dark frass, bits of bark, and silk; they are 25 to $62 \mathrm{~mm}$ long. Pupation occurs in the galleries. The pupae are light brown becoming darker with age. In about three weeks after pupation, the pupae become active and work their way up through the tubelike cocoons to project through the covers for adult emergence. The life cycle may require two to three years.

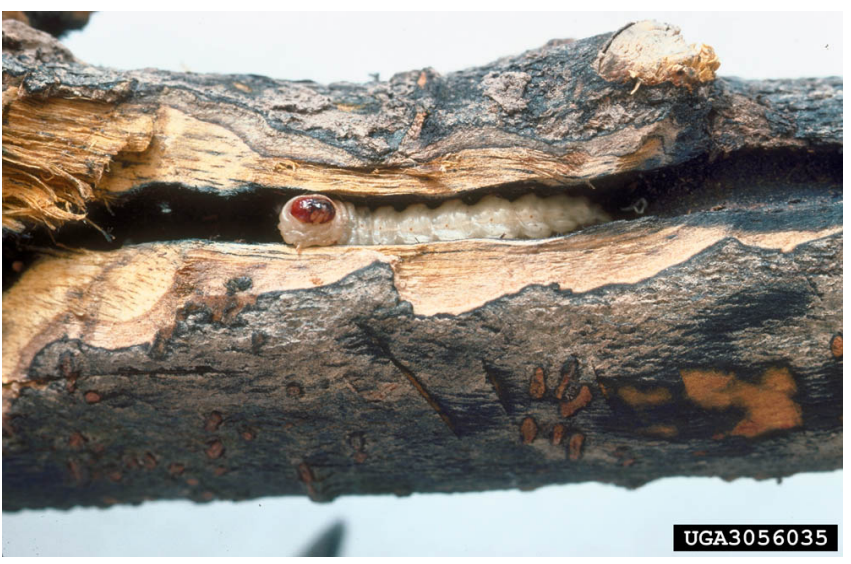

Figure 3. The persimmon borer larva. Credits: James Solomon, USDA Forest Service, www.insectimages.org

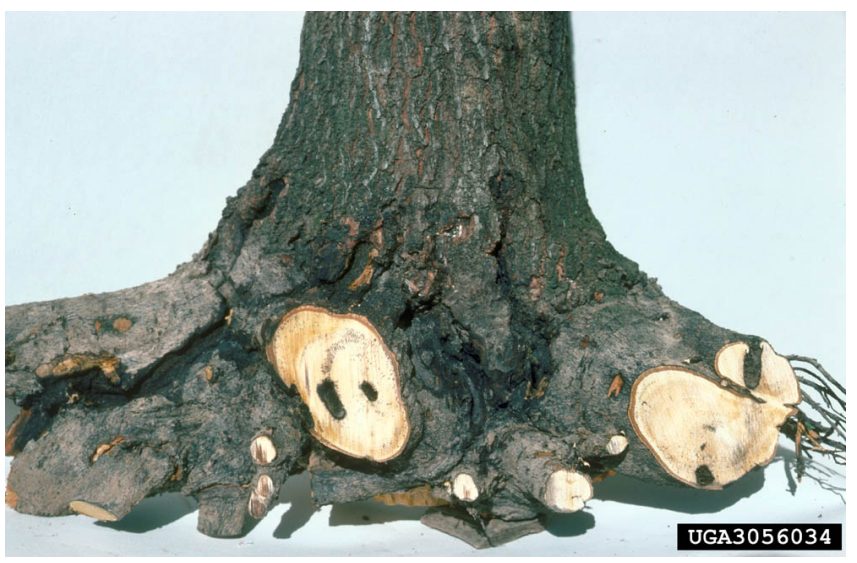

Figure 4. Damage to persimmon by the persimmon borer. Credits: James Solomon, USDA Forest Service, www.insectimages.org

\section{Damage}

Damage is sometimes difficult to diagnose, as most tunneling occurs below ground (Figure 4). However, many attacks are initiated at or slightly above the root collar, providing some evidence for diagnosis. Black gum exudate, particles of bark, and frass are often present, especially during the early stages of attack on the base of the trunks. Sometimes, bark loosens at mined or burrowed sites, exposing tunnels leading down and extending below ground. 


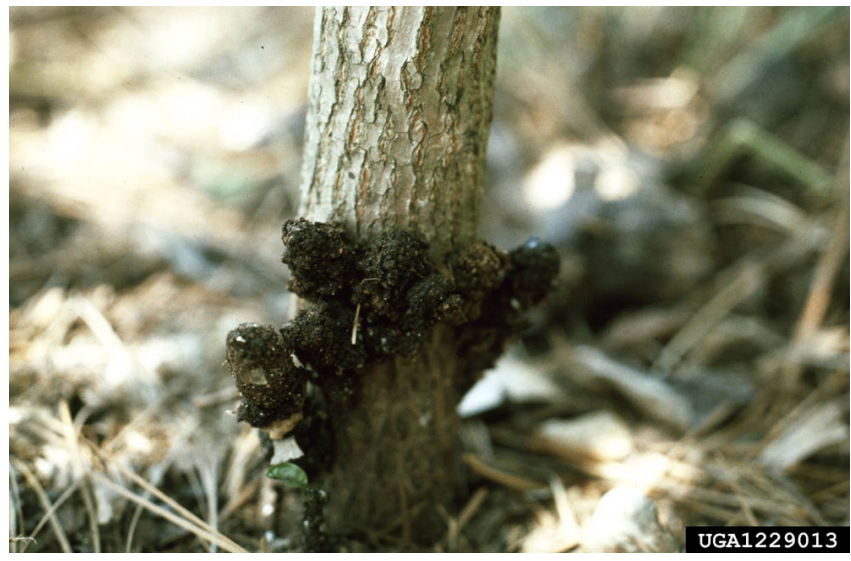

Figure 5. The pupal case of the persimmon borer. Credits: Jerry A. Payne, USDA Agricultural Research Service, www.insectimages.org

Most above ground mines on trunks are just under the bark in the cambium but extend into the wood at or near ground level. Damage can be readily identified by excavating roots (Figure 5). Small roots may be severed or hollowed out, leaving only a shell. Large roots may have two or more galleries. Repeatedly attacked roots will be heavily scarred from previous injury. Heaviest populations occur in young trees 12 to $50 \mathrm{~mm}$ in diameter, but trees up to $20 \mathrm{~cm}$ at the root collar have been found to be moderately infested. Seedlings and young trees in nurseries or young orchards may have their taproots tunneled out, causing them to break off and die. Trees appearing weak and in decline should be examined for this borer. Seedlings and sprouts growing on abandoned fields, roadsides, and ditch banks seem particularly susceptible to attack. Larvae are voracious feeders that tunnel extensively and deeply into roots, weakening and sometimes girdling and killing them. Larval feeding causes seedlings and young saplings to wilt and break. Usually larvae injure large trees less seriously, but populations sometime are large enough to cause weakening.

\section{Controls}

Little is known of natural enemies of this borer. Evidence of woodpecker and rodent excavations of larvae around the base of trees has been observed, but no parasites have been found. No direct controls have been developed, but measures recommended for the peachtree borer would probably be effective. Current research is focusing on biological control with nematodes. Control applications should be timed to the period in spring (March to late June in Florida) when the adults are active to prevent the larvae from entering the wood.

\section{Other Problems}

Other species of woodboring insects and the fungus Bothryosphaeria dothidea also attack persimmon. Unlike $S$. uroceriformis, these species attack the Japanese persimmon scion wood. Several species of metallic wood borers in the family Buprestidae and perhaps other species of Sesiidae attack stressed or injured trees. The usual occurrence in persimmon is as follows. The fungus, B. dothidea, attacks the trees causing cankers that appear as open wounds in the external tree tissue. The adult beetles are attracted to these cankers and lay eggs in the cracks and crevasses that they provide. The beetle larvae then bore under the bark and feed in the conductive tissue, thereby girdling and killing the limbs. In persimmon trees that are not pruned and shaped properly, cracked bark that attracts the beetles may also build up in the crotches of the larger limbs and cause similar damage.

\section{Literature}

Brown, L. N. and R. F. Mizell, III. 1993. The clearwing borers of Florida (Lepidoptera: Sesiidae). Tropical Lepidoptera 4, Suppl. 1. 21 pp. (http://ufinsect.ifas.ufl.edu/clearwing.htm)

Englehardt, G. 1946. The North American clearwing moths of the family Aegeriidae. U.S. National Museum Bull. 190:1-222.

Miller, E. P. and T. E. Crocker. 1994. Oriental persimmons in Florida. (http://edis.ifas.ufl.edu/MG242).

Snow, J. W., T. D. Eichlin, J. H. Tumlinson. 1985. Seasonal captures of clearwing moth (Sesiidae) in traps baited with various formulations of 3,13-octadecadienyl acetate and alcohol. J. Entomol. Sci. 2:73-84.

Solomon, J. D. 1995. Guide to insect borers in North American broadleaf trees and shrubs. USDA-FSAH, AH-706. 